\title{
COMPARISON OF TWO METHODS OF COUNTING MICROSCOPIC CHARCOAL PARTICLES IN PEAT
}

\author{
KAARINA SARMAJA-KORJONEN
}

\begin{abstract}
SARMAJA-KORJONEN, KAARINA, 1991: Comparison of two methods of counting microscopic charcoal particles in peat. Bull. Geol. Soc. Finland 63, Part 1, $41-48$.

A peat monolith of the topmost $92.5 \mathrm{~cm}$ of Slåttmossen, a bog in Helsinki/ Vantaa, S Finland, was analysed for microscopic charcoal with two methods. In the first, the number of charcoal particles was counted, irrespective of their size; in the second, the total area of charcoal was calculated in seven size classes. The peat monolith was also analysed for pollen. The results show that human activity has played an important role in vegetation changes at the site and has also influenced the fire regime, as new land for cultivation was cleared with fire up to the 18th century. The ratio for charcoal and arboreal pollen concentrations was calculated to eliminate the effect of concentration peaks in the more humified peat layers. After these corrections, both methods gave almost identical results; the size class method was not superior in any way. The distribution of larger charcoal particles provided no clear evidence of individual fires nearby.
\end{abstract}

Key words: bogs, peat, charcoal, pollen diagrams, human activity, fires, Holocene, Slåttmossen, Vantaa, Finland.

Kaarina Sarmaja-Korjonen: Department of Geology, Division of Geology and Palaeontology, University of Helsinki, Snellmaninkatu 3, SF 00170 Helsinki, Finland.

\section{Introduction}

Charcoal particle analysis has been used with pollen analysis to study the role of fire in forest development during the Holocene (e.g. Swain 1973, 1978, 1980, Cwynar 1978, Green 1981, Gajewski et al. 1985). Conditions have been particularly auspicious in the New World because the human impact on vegetation in prehistoric times is rarely noticeable.

Since Iversen's pioneering work (1941), charcoal analysis has become an important method for tracing prehistoric agriculture in Europe (M. Tolonen 1978, 1985, 1987, Huttunen 1980, Simmons \& Innes 1981, Andersen 1988, O’Connell et al. 1988). From the Neolithic, cultivated land was cleared with fire. In eastern Finland this slash-and-burn method was practiced until the early years of the twentieth century.

Charcoal particles have been analysed in various ways (see Patterson et al. 1987, K. Tolonen 1983, 1986). In some of the analyses, charcoal particles have been counted by numbers (e.g. Davis 1967, Tallis 1975, M. Tolonen 1985). However, since Waddington's (1969) study, most authors have estimated the total charcoal area $\mu \mathrm{m}^{2}$ by varying numbers of size classes (e.g. Swain 1973, 1978, 1980, Cwynar 1978, M. Tolonen 1978, Amundson \& Wright 1979). Use of the size class counting method is based on the fact 
that large charcoal particles tend to break during laboratory treatment, which can distort the number of particles (Clark 1984). By expressing charcoal as the total area $\mu \mathrm{m}^{2}$ this can be avoided. Charcoal has also often been expressed as the ratio of charcoal area to total pollen.

It has been assumed that large particles indicate a closer fire than small ones, the latter having been considered only a »noise» (Clark 1988). In theory, the size class method should reveal this difference better. Some authors have ignored the small particles and counted just the larger ones (Waddington 1969, Mehringer et al. 1977, Green 1981). There is, however, no agreement about what is the size limit of a large charcoal particle.

The present study compared the counting of charcoal by numbers and by the size class method. As a bog receives charcoal mainly from the air, a bog may be better than a lake in this kind of test, because the lake sediment may often contain allochtonous material as well as pollen and charcoal. A peat monolith, $92.5 \mathrm{~cm}$ deep, from a bog on the border of Helsinki and Vantaa, south Finland, was analysed for charcoal and pollen.

\section{Material and methods}

Slåttmossen (lat. N $60^{\circ} 15^{\prime}$, long. E $25^{\circ} 05^{\prime}$ ) is an ombrotrophic bog with scattered pine trees (Fig. 1). Covering an area of about 25 ha, it lies in an area of glaciofluvial deposits (VuosaariHakkila formation). The blocks of flats (Jakomäki), industrial complexes and many roads built in the area have altered the topography around the site (Fig. 1) so much that the ancient landscape cannot be reconstructed.

The samples were taken in August 1984. A one-metre deep pit was dug in Sphagnitm peat. A monolith measuring $10 \times 10 \times 100 \mathrm{~cm}$ was cut from the wall with a knife. During lifting and packing, the monolith was pressed to a length of $92.5 \mathrm{~cm}$. The stratigraphy of the monolith is mainly unhumified Sphagnum peat (Humositas
$2 / 10$ ) with two darker, slightly more humified (Hum. 3/10) layers (42.5-52.5 $\mathrm{cm}$ and 70$75 \mathrm{~cm})$.

The subsamples for pollen analysis were taken at $2.5 \mathrm{~cm}$ intervals. The samples were weighed without drying and Lycopodium spore tablets were added for concentration calculations (Stockmarr 1971). The coarser organic material was removed by sieving after $\mathrm{KOH}$ treatment followed by the standard procedure with acetolysis (Fægri \& Iversen 1975). The samples were stored in small tubes in clycerol stained with safranin. $1000 \mathrm{AP}$ grains (+ NAP and spores) were counted in each sample.

The abbreviation CIP refers to cultural indicator pollen types. The CIP curve (Fig. 3) includes the following pollen types: Rumex acetosa/acetosella type, Centaurea cyanus, Plantago major, P. lanceolata, Polygonum aviculare type, Ranunculus acris type, Caryophyllaceae, Brassicaceae, Cichoriaceae, Asteraceae and Chenopodiaceae. The Cerealia curve also includes Secale.

The microscopic charcoal particles were counted from the same slides as the pollen grains with two methods:

Method 1. The microscopic charcoal particles were counted during pollen analysis. All particles exceeding $5 \mu \mathrm{m}$ in diameter were recorded. The number of charcoal particles was calculated first as a percentage of the total pollen sum (P). As Lycopodium tablet spores were counted, the concentration of charcoal particles could also be calculated.

Method 2. The charcoal analysis was made after the pollen analysis. The seven size classes used were determined with the scale of the microscope. Each particle was included in one of the following size classes, whichever was closest to its size: $25 \mu \mathrm{m}^{2}, 64 \mu \mathrm{m}^{2}, 160 \mu \mathrm{m}^{2}, 224 \mu \mathrm{m}^{2}, 320 \mu \mathrm{m}^{2}$, $448 \mu \mathrm{m}^{2}$ and $448-3200 \mu \mathrm{m}^{2}$. The particles in the last size class were each measured separately. A few particles larger than $3200 \mu \mathrm{m}^{2}$ were found. The chance of finding them was considered too much a matter of chance, and their size was not 
Fig. 1. Location of the study site. The topography has been altered by the building of houses, factories and roads (vertical hatching = altered topography). The sampling site is marked with a cross.

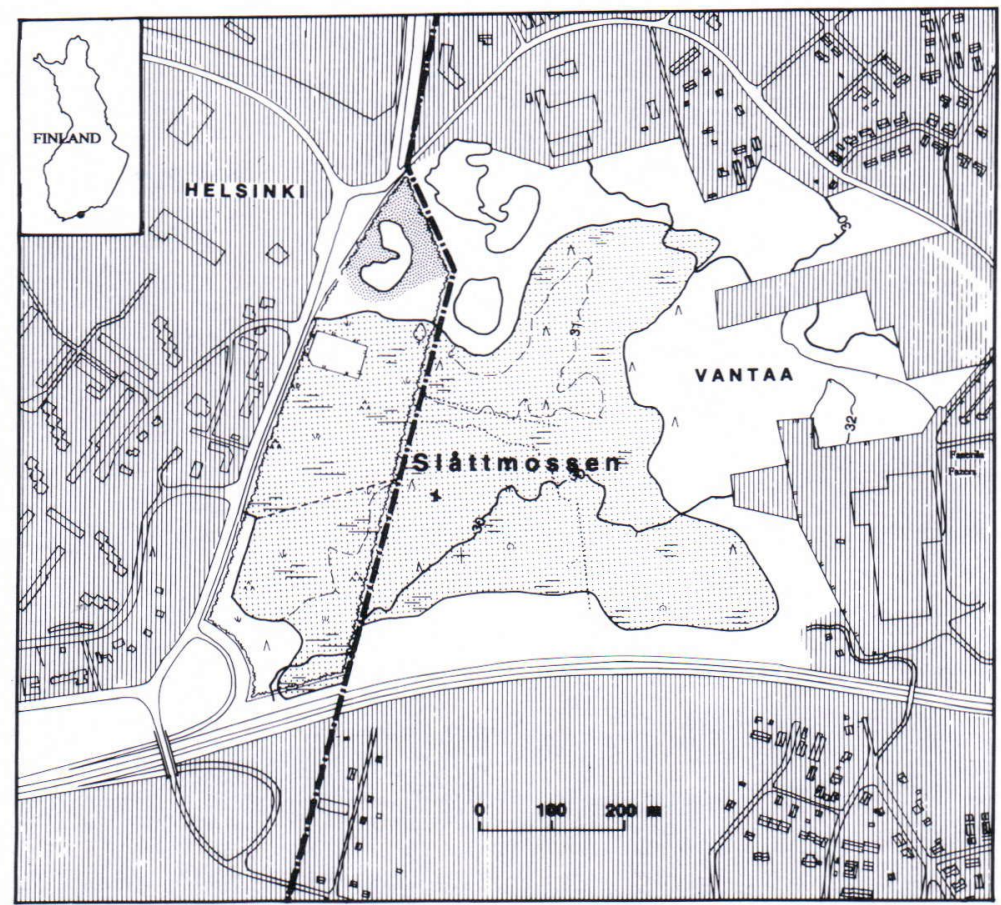

included in the calculations (see also K. Tolonen 1986, p. 492). However, their occurrence was recorded. The total area of charcoal $\mathrm{g}^{-1}$ was calculated.

The charcoal concentration/AP concentration ratio was calculated from the results obtained with both methods. The total pollen concentration was not used in the calculations because it includes the local NAP component (e.g. Ericales) with abrupt fluctuations. The AP input was considered the most reliable constant available. The percentages of charcoal particles in each size class were also calculated. The basic sum was the number of all charcoal particles counted within each spectrum with method 2 .

\section{Results}

\section{Pollen analysis}

There are three horizons with exceptionally high pollen concentrations $(70 \mathrm{~cm}, 42.5 \mathrm{~cm}$ and
$25 \mathrm{~cm}$; Fig. 2). As concentrations of all the main tree species are high, the concentrartion peaks cannot be due to local Pinus pollen alone as might be the case as scattered pine trees still grow on the bog. The $70 \mathrm{~cm}$ and $42.5 \mathrm{~cm}$ horizons are visible as darker layers in the stratigraphy, and the degree of humification changes from 2 to 3 . No change of humification can be seen at $25 \mathrm{~cm}$. These concentration maxima evidently represent horizons where Sphagnum peat grew more slowly. The three horizons with high concentrations are marked in the diagrams as concentration maximum horizons A $(70 \mathrm{~cm}), \mathrm{B}(42.5 \mathrm{~cm})$ and C $(25 \mathrm{~cm})$.

The pollen diagram (Fig. 3) is divided into two local pollen assemblage zones depending on the degree of human disturbance:

$$
\text { paz SL1 }(92,5-45 \mathrm{~cm})
$$

Concentration maximum horizon A divides the zone into two parts. Up to $70 \mathrm{~cm}$ the proportions of trees remain fairly stable, and human impact 


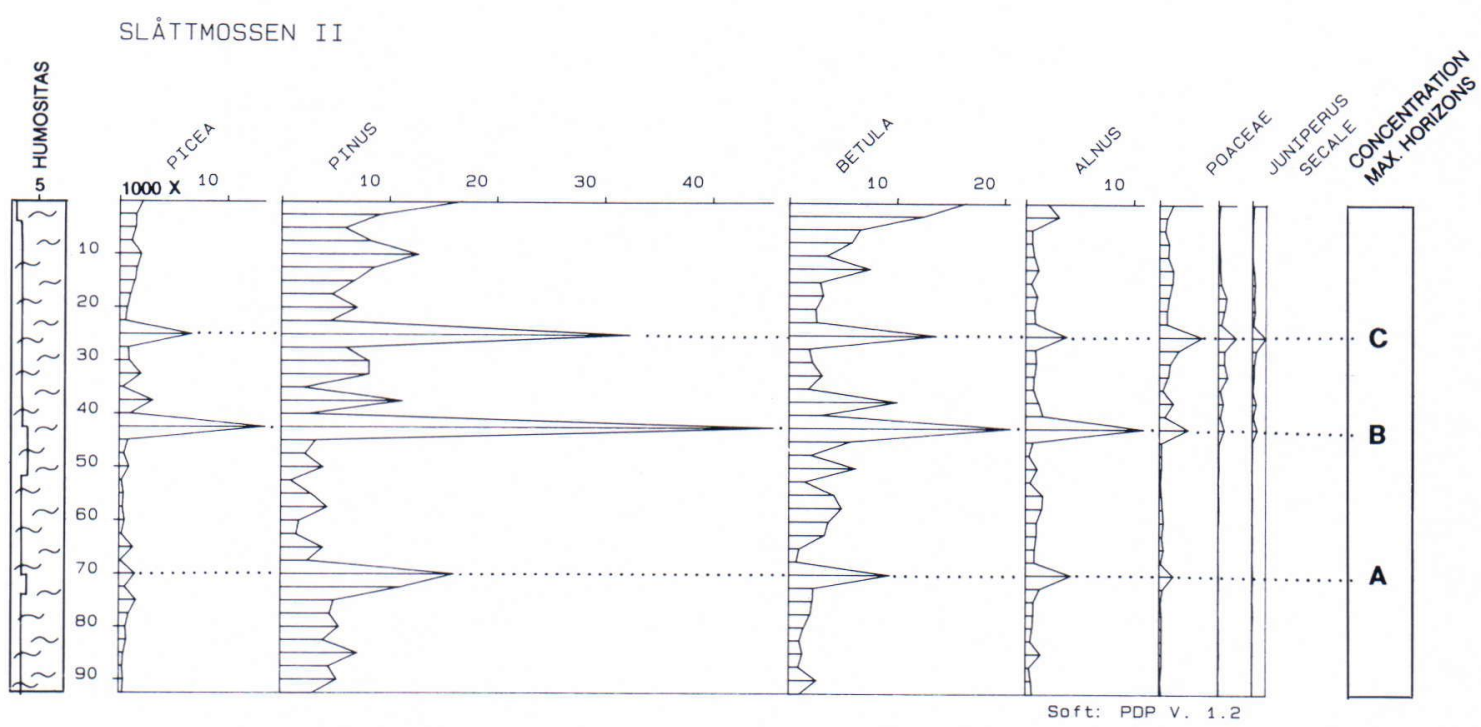

Fig. 2. Slåttmossen, Helsinki/Vantaa. Pollen concentration values $g^{-1}$.

on the landscape must have been moderate judging by the low values of Juniperus, Poaceae, Cerealia and other CIP (including Plantago lanceolata, Ranunculus acris type and Brassicaceae).

At $72.5-70 \mathrm{~cm}$, peat grew more slowly for an unknown reason. After that the AP relations change dramatically, with the conifers (Picea and Pinus) decreasing and Betula and Alnus increasing. New CIP types (e.g. Centaurea cyanus, Plantago major and Polygonum aviculare) appear. The higher values of Ericaceae and Calluna most probably indicate changes of the vegetation of the bog itself.

paz SL2 $(45-0 \mathrm{~cm})$

The indicators of cultivation and other human activities (e.g. Juniperus, Poaceae, Cerealia and other CIP) increase markedly. Pinus values are high again in this zone. No changes in pollen spectra can be linked with concentration maximum horizon $\mathrm{C}(25 \mathrm{~cm})$.

\section{Charcoal analysis}

Method 1. - The quantity of charcoal parti- cles expressed as percentages of the total pollen sum is presented in Fig. 4. When the concentration of the charcoal particles was calculated (not drawn in Fig. 4) it merely echoed the trends in the pollen concentrations: the charcoal peaks were at the same levels as the pollen concentration maxima.

The charcoal particle concentration/AP concentration curve approximately follows the peaks and trends of the percentage curve: at the base of the monolith the amount of charcoal is small. Between 80 and $20 \mathrm{~cm}$ there are several charcoal peaks, with an increasing trend upwards. At 20 $\mathrm{cm}$ the amount of charcoal rises abruptly.

Method 2. - The curve for the total area of charcoal (Fig. 4) again reflects simply the concentration maximum horizons. On the other hand, the curve for the total charcoal area/AP concentration ratio (Fig. 4) is almost identical to that of the charcoal particle concentration/AP concentration.

Size classes. - Fig. 5 shows the percentages of different size classes of charcoal particles. No clear variations are visible except for fluctuations in the two smallest sizes between 85 and $47.5 \mathrm{~cm}$. 

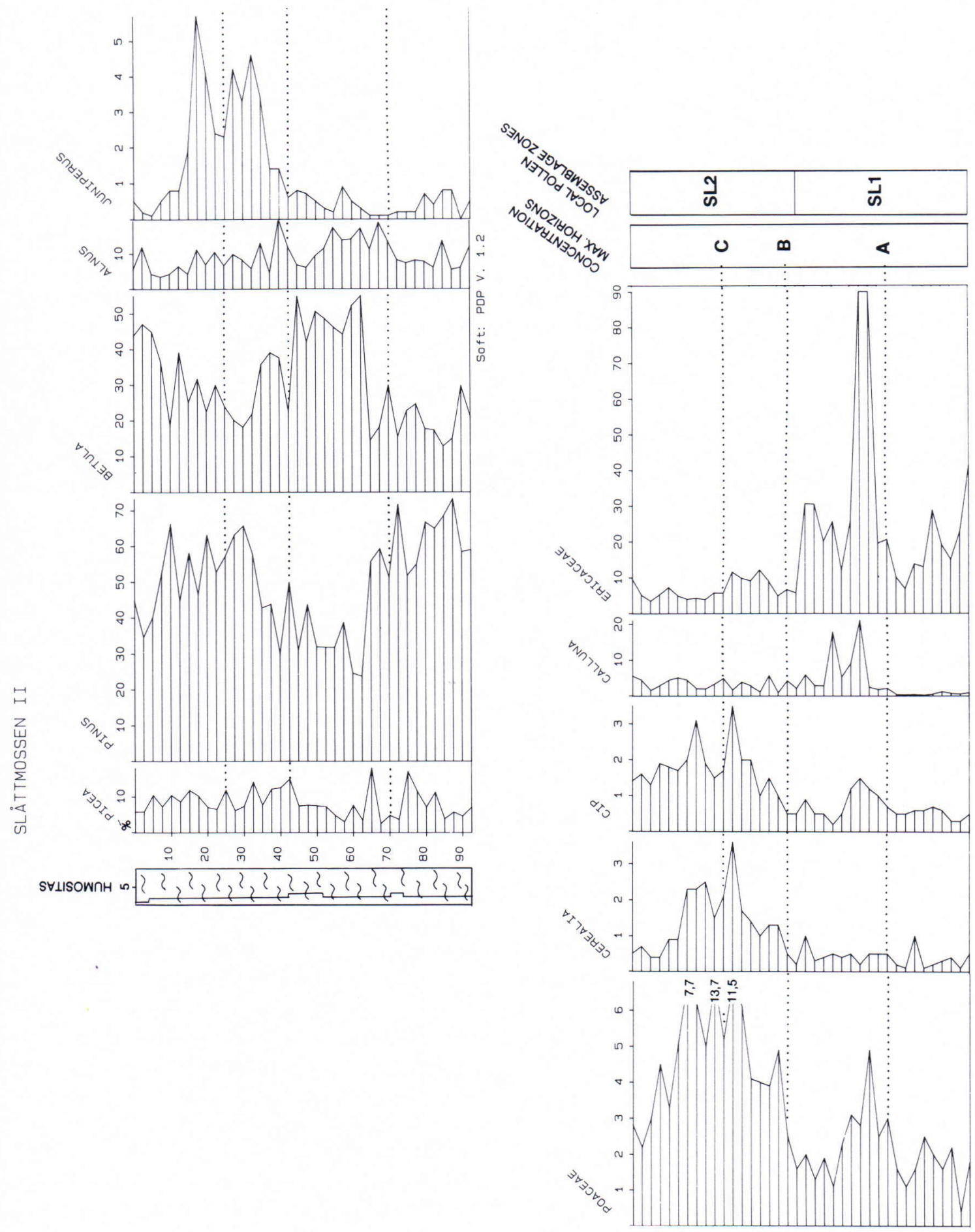

Fig. 3. Slåttmossen, Helsinki/Vantaa. Pollen percentage diagram with selected pollen types. The list of pollen types included in the CIP curve is given in the text. 


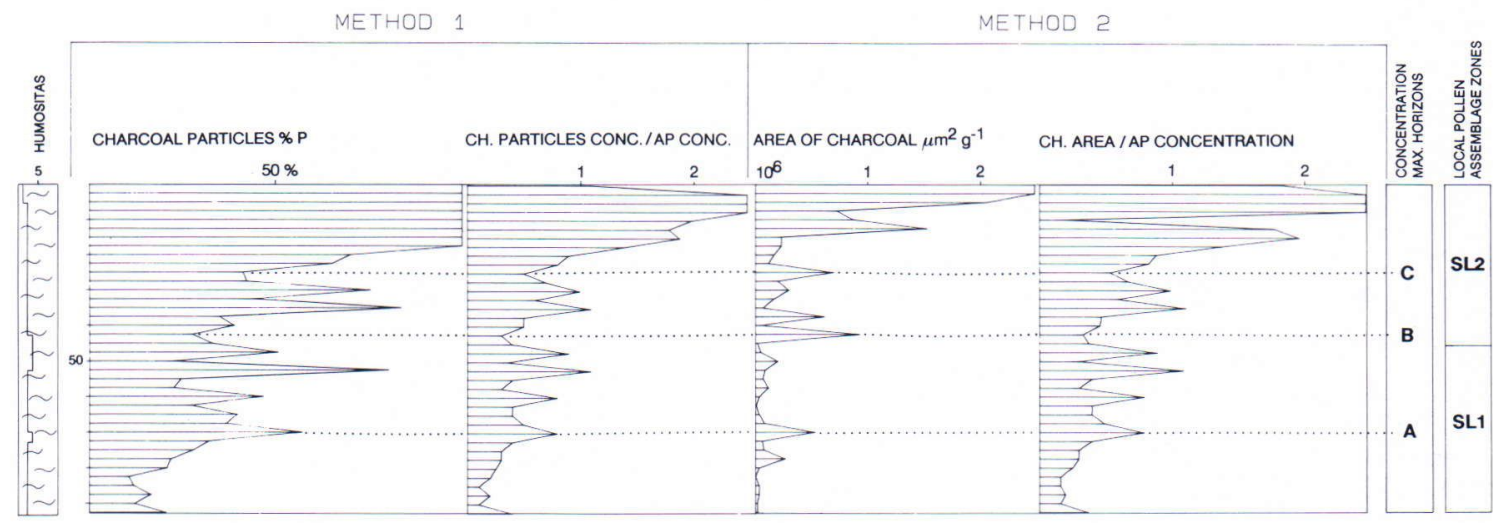

Fig. 4. Slåttmossen, Helsinki/Vantaa. Comparison of different methods of calculating microscopic charcoal in peat. The methods and ways of expressing charcoal quantity are 1) particles $\%$ of the total pollen sum, 2) the charcoal particle concentration/AP concentration ratio, 3 ) the total surface area of charcoal particles $\left.\mu \mathrm{m}^{2} \mathrm{~g}-1,4\right)$ the total charcoal surface area/AP concentration ratio.

No far-reaching conclusions can be drawn from these, however, because the sizes in question are the two smallest, and are in fact, very small indeed.

\section{Conclusions and discussion}

Human impact on the vegetation is seen throughout the pollen stratigraphy, first, as faint signs of cultivation, and then, in local paz SL2, clearly together with indicators of cattle raising. Most of the charcoal record can be linked with these human activities, as slash-and-burn cultivation was widely practiced up to the 18 th century also in rural areas near Helsinki (Voionmaa 1950 , p. 84). The area was permanently inhabited at least from the early Middle Ages (AD 1150-) onwards (Voionmaa 1950).

At Slåttmossen the layers of more humified peat showed dramatic fluctuations in the concentrations of pollen and of charcoal counted by both methods. The relative charcoal values turned out to be more reliable indicators of the real charcoal input. The two methods gave almost identical results in calculations of the charcoal/ AP concentration ratio (see also Patterson et al. 1987 , p. 13). M. Tolonen (1985, p. 18) also obtained the same trends when counting charcoal by numbers and with four size classes. She calculated the ratios of charcoal to the total pollen sum. At Slåttmossen the AP concentration was preferred because of the sharp fluctuations in local NAP.

No in situ fire horizons were visible at the Slåttmossen profile and therefore the charcoal must all have been airborne. It would be tempting to assume that the different charcoal peaks in the Slåttmossen profile represent individual fires around the bog, whether caused by natural events or by human activities. Each sample, however, contains pollen and charcoal deposited over so many years that the peaks may represent either the »diluted» remains of very heavy charcoal rain after individual fires or each peak may represent several fires (see also simulations in Clark 1988). The size class percentages (Fig. 5) yielded no clear peaks of large charcoal particles as signs of fires near the site.

The charcoal counting experiments on the 


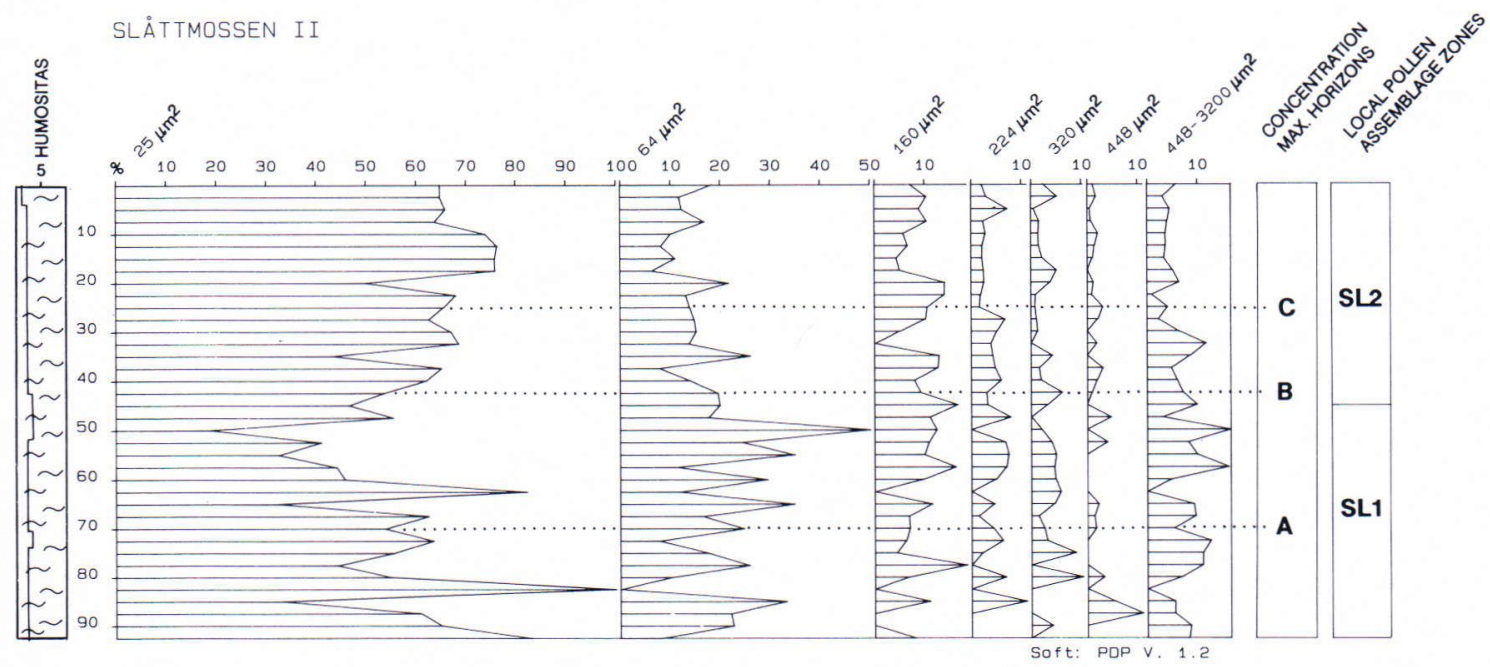

Fig. 5. Slåttmossen, Helsinki/Vantaa. Different size classes of microscopic charcoal expressed as percentages of the total charcoal particle sum counted for each sample.

Slåttmossen profile using both quantity and surface area methods gave fairly similar results and may both be useful if correction ratios are calculated. No hints of the superiority of the size class method were obtained.

\section{References}

Amundson, D.C. \& Wright, H.E., Jr., 1979. Forest changes in Minnesota at the end of the Pleistocene. Ecological Monographs 1979, 1-16.

Andersen, S.T., 1988. Changes in agricultural practices in the Holocene indicated in a pollen diagram from a small hollow in Denmark. In Birks, H.H., Birks, H.J.B., Kaland, P.E. \& Moe, D. (Eds.), The Cultural Landscape - Past, Present and Future, Cambridge University Press, Cambridge, pp. 395-408.

Clark, J.S., 1988. Particle motion and the theory of charcoal analysis: source area, transport, deposition, and sampling. Quaternary Research 30, 67-80.

Clark, R.L., 1984. Effects on charcoal of pollen preparation procedures. Pollen et Spores 24, 559-576.

Cwynar, L.C., 1978. Recent history of fire and vegetation from laminated sediment of Greenleaf Lake, Algonquin Park, Ontario. Can. J. Bot. 56, 10-21.

Davis, R.B., 1967. Pollen studies of near-surface sediments in Maine lakes. In Cushing, E.J. \& Wright,H.E. (Eds.),
Aknowledgements. I would like to thank Mr Väinö Hosiaisluoma and my husband, Kari Korjonen, for help in the field. I am also most grateful to Dr. Irmeli Vuorela for valuable comments on the manuscript and Mrs. Pirjo Haikonen for drawing the map.

Quaternary Palaeoecology, Yale University Press, New Haven, pp. 143-174..

Faegri, K., Iversen, J., 1975. Textbook of pollen analysis. 3rd rev. ed. Munksgaard, Vojens, $295 \mathrm{p}$.

Gajewski,K., Winkler, M.G. \& Swain, A.M., 1985. Vegetation and fire history from three lakes with varved sediments in northwestern Wisconsin (U.S.A.). Rev. Palaeobot. Palynol. 44, 277-292.

Green, D.G., 1981. Time series and postglacial forest ecology. Quaternary Research 15, 265-277.

Huttunen, P., 1980. Early land use, especially the slash-andburn cultivation in the commune of Lammi, southern Finland, interpreted mainly using pollen and charcoal analyses. Acta Bot. Fennica 113, 45 p.

Iversen, J., 1941. Land occupation in Denmark's Stone Age. Danmarks Geologiske Undersøgelse, II Række Nr. 66, $68 \mathrm{p}$.

Mehringer, P.J., Jr., Arno, S.F. \& Petersen, K.L. 1977. Postglacial history of Lost Trail Pass Bog, Bitterroot Mountains, Montana. Arctic and Alpine Research 9, 345-368.

O'Connell, M., Molloy, K. \& Bowler, M., 1988. Post-glacial 
landscape evolution in Connemara, western Ireland with particular reference to woodland history. In Birks, H.H., Birks, H.J.B., Kaland, P.E. \& Moe, D. (Eds.), The Cultural Landscape - Past, Present and Future, Cambridge University Press, Cambridge, pp. 267-287

Patterson, W.A., III, Edwards, K., J., Maguire, D.J., 1987. Microscopic charcoal as a fossil indicator of fire. Quaternary Science Reviews 6, 3-23.

Simmons, I.G. \& Innes, J.B., 1981. Tree remains in a North York Moors peat profile. Nature 294, 76-78.

Stockmarr, J., 1971. Tablets with spores used in absolute pollen analysis. Pollen et Spores 13, 615-621.

Swain, A.M., 1973. A history of fire and vegetation in Northeastern Minnesota as recorded in lake sediments. Quaternary Research 3, 383-396.

-, 1978. Environmental changes during the past 2000 years in north-central Wisconsin: analysis of pollen, charcoal, and seeds from varved lake sediments. Quaternary Research $10,55-68$.

-, 1980. Landscape patterns and forest history in the Boundary Waters Canoe area, Minnesota: a pollen study from Hug Lake. Ecology, 61, 747-754.

Tallis, J.H., 1975. Tree remains in southern Pennine peats. Nature 256, 482-484.

Tolonen, K., 1983. The post-glacial fire record. In Wein, R.W. \& MacLean, D.A. (Eds.), The Role of Fire in
Nothern Circumpolar Ecosystems, John Wiley \& Sons, pp. $21-44$.

-, 1986. Charred particle analysis. In Berglund, B.E. (Ed.), Handbook of Holocene Palaeoecology and palaeohydrology, John Wiley \& Sons, pp. 485-496.

Tolonen, M., 1978. Palaeoecology of annually laminated sediments in Lake Ahvenainen, S. Finland. I. Pollen and charcoal analyses and their relation to human impact. Ann. Bot. Fennici 15, 177-208.

-, 1985. Palaeoecological record of local fire history from a peat deposit in SW Finland. Ann. Bot. Fennici 22, $15-29$.

-, 1987. Primary and secondary forest successions reflected in a late Holocene pollen sequence from an upland mire near the SW coast of Finland. Ann. Bot. Fennici 24, 97-109.

Voionmaa, V., 1950. Helsingin seudun historiaa ennen kaupungin perustamista. In Helsingin kaupungin historia I, 79-108. Helsingin kaupunki, Helsinki.

Waddington, J.C.B., 1969. A stratigraphic record of the pollen influx to a lake in the Big Woods of Minnesota. Geological Society of America, Special Paper 123, 263-282.

Received December 10, 1990

Revision accepted March 15, 1991 